\title{
Forest Operations and Ecosystems Services in Norway - A Review of the Issues at Hand and the Opportunities Offered through New Technologies
}

\author{
Bruce Talbot ${ }^{1}$ and Rasmus Astrup ${ }^{2}$ \\ ${ }^{1}$ Department of Forest Technology, Norwegian Forest and Landscape Institute, \\ P.O. Box 115, 1431 Ås, Norway \\ ${ }^{2}$ Department of Forest Resources, Norwegian Forest and Landscape Institute, \\ P.O. Box 115, 1431 Ås, Norway \\ Corresponding Authors: $\{$ bta;raa $\} @$ skogoglandskap.no
}

Received 17 October 2014; Accepted 27 November 2014;

Publication 19 March 2015

\begin{abstract}
It is widely recognized that forests should be managed inter alia for the provision of timber, biomass for energy, bio-chemicals, biological diversity, carbon storage, water purification, outdoor recreation and other ecosystem services. Forest operations are the most costly part of forest management and at the same time can be traced to most of the negative externalities on the environment often with strong visual impacts, especially in steep terrain. This paper reviews emerging technology-based engineering solutions that may reduce the impact of forest operations on the environment while increasing the efficiency of operations resulting in an overall higher level of forest ecosystem service provision. Advances in forest machine control and automation systems, and the availability of remotely-sensed high resolution data now provide considerable potential to improve the management and precision of forest operations. Improved planning procedures and more precise operations offer a considerable opportunity for mitigating environmental damage. Accurate positioning of operations machinery allows for the generation
\end{abstract}

Journal of Green Engineering, Vol. 4, 271-290.

doi: 10.13052/jge1904-4720.442

(c) 2014 River Publishers. All rights reserved. 
of automated warnings in the case of transgressing property or key habitat boundaries. Terrain models derived from airborne laser scanning (ALS) data have been shown to be useful in locating effective extraction trails or timber landings, thereby increasing efficiency and reducing site impact such as rutting and compaction.

Keywords: Timber harvesting, logging, forest operations, environmental impact.

\section{Introduction}

Norway has an area of 8.2 million ha of productive forest [1] and a low population density (14 people per $\mathrm{km}^{2}$ ), and has similar expectations for the provision of ecosystems services from forests as do highly populated countries like Germany (230 people per $\mathrm{km}^{2}$ ) and France (121 people per $\mathrm{km}^{2}$ ) [2]. A recent report commissioned by the Norwegian Ministry of the Environment emphasises the importance of forests managed inter alia for the provision of timber, biomass for energy, bio-chemicals, biological diversity, carbon storage, water purification and outdoor recreation [3]. These expectations with regard to forest based services are not unique to Norway, but are in fact universal [4].

Primary energy supply and land use scenarios envisage a future that is more heavily reliant on terrestrial ecosystems to supply food, fiber, and energy $[5,6]$. The scale of the transformation challenge is enormous in a world where land resources are already scarce [7]. It is widely recognized that an increased reliance on forest for the provision of fiber will pose a threat to biodiversity and other ecosystem services [8]. Besides, an active and profitable Norwegian forest sector with a competitive forest industry is essential for rural development in large parts of the country [9]. The government intends to strengthen the value-adding capability of the forestry sector, with the goal of mobilizing resources for commercial development and climate change mitigation [9]. The current annual volume of roundwood sales in Norway is about 9 mill $\mathrm{m}^{3}$ but an annual growth of almost three times that indicates a significant potential for increased procurement of Norwegian forest fiber [1].

Norway has a high-cost society and the forest sector is struggling to stay competitive in the global market. Despite phenomenal efficiency gains over the past half-century, logging remains the most cost intensive part of forest management [10]. Forest operations are not only costly, they also cause the largest negative externalities on the environment and have the strongest 
visual impact [11], especially in steep terrain. The public debate related to the environmental impact of forestry is intense. As observed in other parts of the world, this poses a threat to the social license to practice [12] leading to political and public resistance towards further development of the forest-based bio-economy. Hence, when considering the development of the Norwegian forest sector as an economic, social and environmentally sustainable pillar of the bio-economy, a strong emphasis should be placed on the economic and environmental efficiency of harvesting operations. Environmental efficiency comes about through minimizing environmental damage for a given production output. However, environmental efficiency studies are virtually non-existent in forestry, but are more common in agricultural production settings [13-15].

Forest engineering, applied as a professional scientific discipline, involves both developing and maintaining the infrastructure necessary in accessing forests for any purpose, as well as designing tools, machines, machine systems and work methods for carrying out forest management tasks. Forest engineering, as a sub-discipline of environmental engineering, and the way in which it is practiced, is therefore central to any debate regarding the goods and services produced on forest land. The two leading forest certification schemes in Norway; the Forest Stewardship Council (FSC) [16] and the Programme for the Endorsement of Forest Certification (PEFC) [17] have developed a set of sustainability indicators that include elements related to forest operations. The Norwegian association of heavy equipment contractors (MEF), which includes timber harvesting contractors, are full members of PEFC, and their members are therefore obliged to follow the guideline set by the PEFC 'Living Forest Standard' which was drafted by a range of organisations representing outdoor recreation, forest owners, the Norwegian biodiversity network, industrial associations, and WWF Norway [18]. The standard states that the harvesting potential should be exploited within a framework set by economic, biodiversity and other environmental considerations and values. In addition the standard maintains that a higher share of selection cutting should be carried out through thinning, and the selection of harvesting methods and the implementation of the harvest should be adapted to local conditions, maintain local environmental qualities, take due consideration of the landscape and ensure conditions for satisfactory regeneration with species suited to the local growing area [18].

Issues of direct relevance to the way forest operations are carried are:

- Requirements on the workforce and their qualifications: Training courses run continuously at the Norwegian Forestry Extension Institute and 
skill development in steep terrain logging documented through research $[19,20]$.

- Waste management, here especially engine and hydraulic oil, spares, steel cable, chains etc., as well as a requirement to use the best available technology (BAT).

- Key habitats: The management of at least $5 \%$ of productive forest as areas of ecological importance, requiring the documentation and registration of these areas. With regard to mountain forests, the standard requires that the harvesting methods for spruce must follow the "mountain forest selection cutting system" as far as possible. Small-scale clear-cutting and smaller seed tree stand felling should be used as far as possible to promote regeneration in the pine forest. The importance of protection forests against landslides in this area has recently been addressed [21].

- Outdoor recreation: Forest management activities must consider maintaining the quality of outdoor experiences, especially along hiking and skiing trails. All commercial activity in forest areas must be conducted in such a way that the de facto content of the right of unimpeded access is maintained.

Wheel tracks that cause water runoff and erosion, transport damage to hiking and ski trails and other significant damage must be repaired as soon as moisture conditions permit once the extraction trail is no longer in use. Excessive wheel rutting (Figure 2, right) and the placement of harvesting residues are two of the most common problems experienced by forest visitors.

While the Norwegian forest sector is appreciably smaller than those of neighbouring Sweden and Finland (which harvest around 80 and 70 million $\mathrm{m}^{3}$ $\mathrm{a}^{-1}$ respectively), much of the forest area is found in steep, difficult, or highly susceptible terrain, providing a challenge to forest engineering in suggesting environmentally acceptable solutions. This paper builds on the hypothesis that environmental damage directly or indirectly impairs the capacity of the forest to provide the ecosystems services desired by society. Only the most obvious physical forms of environmental or ecological damage are included in this paper, and these are categorised below as a frame of reference:

- Efficiency of resource utilisation and damage to key woodland habitats

- Soil and Water: rutting, compaction, surface and gulley erosion, turbidity and sedimentation

- Aesthetic and cultural heritage impacts, as well as impacts on the recreational use of forests 
The paper focuses on a review of emerging technology-based solutions that may reduce the impact of forest operations on the environment while increasing the efficiency of operations. Hence, the paper does not address issues around changes to ecosystem functionality, neither does it consider water table fluctuations or influences on bio-geochemical cycles (including carbon fluxes) from the utilisation of various tree parts or harvesting regimes.

\section{Key Organisational and Technical Advances Available to the Forest Operations Manager}

Advances in forest machine control and automation systems, and the availability of remotely-sensed high resolution data now provide considerable potential to improve the management and precision of forest operations [22]. Improved planning procedures, and more precise operations offer a considerable opportunity for mitigating environmental damage. The utilization, productivity and economic efficiency of forest machines, and meeting of specific product orders, is fully dependent on planning both within and between stands [23]. The direct cost of relocation alone can account for $10 \%$ of the harvesting price [24], which could be reduced through improved scheduling [23, 25]. In scheduling, machines can be ranked and allocated to stands on a broad range of environmental and performance criteria, including the interacting relationships of harvest season, soil texture, bulk density, surface soil strength and position in the landscape [26]. Furthermore, planning a harvest sequence at a landscape level with the inclusion of adjacency constraints, can reduce visual impact, erosion, landslide or avalanche danger, and enhance biodiversity [27]. However, advances in planning are wholly reliant on technical developments that are able to capture or convert large amounts of data into improved operational information. The following subsections will attempt to demonstrate the importance of the data collected and highlight applications of this data in emerging research.

\subsection{Efficient Resource Utilisation and Avoidance of Damage to Key Woodland Habitats}

Forest machine performance can be captured continuously using a combination of on-board productivity monitoring systems, including the StanForD data management system [28], CAN-bus machine performance data, and external sensor data $[29,30]$. 
Accurate positioning of base machines allows for the generation of automated warnings in the case of transgressing property or key habitat boundaries, and also allows for machines to accurately log information on residual trees or other important sites or cultural heritage vestiges identified during harvesting. Accurate positioning of forest machines on steep slopes of fjords at high northern latitudes remains a significant challenge in carrying out precision forestry operations as both the azimuth and limited time windows for satellite connection present difficulties. Global Navigation Satellite System (GNSS) information can be enhanced with terrain surface information [31], and possibly supplemented with other positioning techniques such as laser [32] or visual telemetry based solutions [33], simultaneous location and mapping (SLAM) [34], and inertial navigation systems (INS) [35].

Terrain and tree size and species distributions have the largest effect on productivity [36] and can now be remotely assessed through airborne laser scanning (ALS). Stand-level bucking, which allows for detailed product recovery to be calculated from ALS data provides for a more accurate selection of stands for harvesting, both in time and space [37], and could therefore be an important parameter in future studies on environmental efficiency, where a detailed product output portfolio could be held up against an index of anticipated environmental damage [14]. The inclusion of stand level bucking prognoses from terrestrial scanning [38] or from inventory data, in completely new approaches to tactical planning $[39,40]$ potentially represents an important shift toward value maximization planning. As bucking patterns both strongly affect production [41] and transport costs and energy consumption [42], they play an important role in the entire procurement system [43]. The development of more agile, value maximizing supply chains could play an important role in revitalizing an economically and environmentally efficient Norwegian timber harvesting sector.

\subsection{Soil and Water}

Forests in wetter climates provide a stabilizing buffer in the hydrological cycle, reducing surface run-off and its associated erosional energy [44], regulating release to waterways [45] and promoting percolation of uncontaminated water to aquifers, as forest soils are generally subjected to fewer or no chemicals or fertilizers [46]. Impacts on soil and water related to forest engineering largely arise from both the construction and maintenance of forest infrastructure and from machinery in the harvesting and extraction of timber. With regard to forest roads, the Norwegian Ministry of Environment (MoE) report on Ecosystems 
Services [3] highlights one of many ecosystem service trade-off dilemmas arising from joint ambitions of utilisation and protection, as the encroachment of roads is criticised as being detrimental to biodiversity and the wilderness experience through forest segmentation on the one hand, while their absolute necessity in facilitating a rational utilisation of forest products, as well as the access they provide to the recreational use of forests and mountain rangelands above the forest line is highlighted on the other.

The Norwegian forest road network remains sparse in relation to comparable countries, and is generally below $10 \mathrm{~m} \mathrm{ha}^{-1}$, with only $3-5 \mathrm{~m} \mathrm{ha}^{-1}$ in the steep terrain in the coastal area. In total, some 400000 ha of mature timber are located more than $2 \mathrm{~km}$ from a forest road, 728000 ha between 1 and $2 \mathrm{~km}$, and 782000 ha between $500 \mathrm{~m}$ and $1 \mathrm{~km}$ from a road [1]. As road transport is at least 20 times more efficient than terrain transport [47] there is a strong incentive to expand the forest road network. The use of modern technology such ALS data help with detailed planning of forest roads, ensuring that they are as environmentally benign as possible. Examples of this are given by Aruga et al [48], who minimize sedimentation through improved road design, and Contreras et al [49] who apply road design geometry to an ALS derived DEM in estimating earthwork requirements. Related work employing ALS includes the mapping of gullies and headwater streams [50] and the estimation of gully erosion [51]. In Norway, increased rainfall intensity and magnitude has resulted in a recent revision of the forest road construction standards, stipulating amongst other things, changes to the frequency and dimension of drains [52].

As forests on the Norwegian west coast constitute an area of high rainfall $\left(>2000 \mathrm{~mm} \mathrm{a}^{-1}\right)$ with steep terrain $\left(15\right.$ million $\mathrm{m}^{3}$ of mature timber on slopes over 50\% [1] and a low forest road network, they simultaneously offer a wide range of ecosystems services and are themselves highly susceptible to inadvertent damage through harvesting practices. Access to these stands is gained either by the construction of temporary skid trails which allow access to ground based fully mechanized systems (harvester-forwarder) (Figure 1, left) or by cable-yarders specially constructed on terrain-going base machines enabling them to work at some distance from a forest road (Figure 1, right). While cable-yarders minimise impact to the slope by partially suspending the trees during extraction, skid trail construction is a matter of some environmental concern [53] and a novel method of monitoring the extent of soil displacement arising from it has recently been tested in this area using drones [54]. Skid trails can be de-activated through a number of means with varying results [55, 56] and at various costs [57], although a reduced need for a skid trails in conjunction with improved planning procedures is the preferable option [58]. 


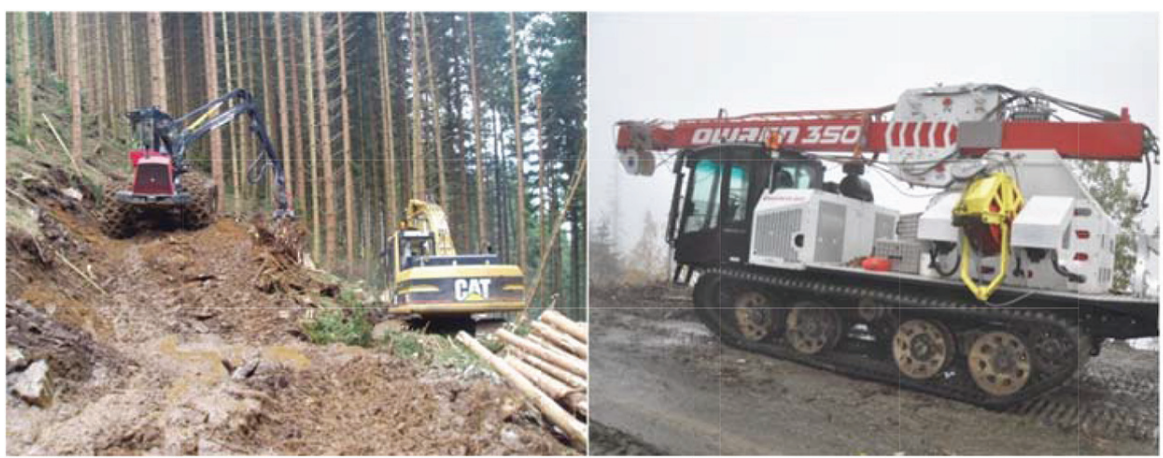

Figure 1 (left) construction of temporary skid trails in steep terrain and (right) specially developed Owren 350 terrain-going tower yarder for accessing sites with low bearing capacity or some distance from the forest road network.

Norway is renowned for its salmonid populations, which are associated with almost all the country's watersheds. Some 330 tonnes of wild salmon, sea trout and migratory char were caught by recreational anglers in 2013 [59], making fishing a significant contributor to the nature-based tourism portfolio. Sediment from forest roads and forest operations is known to impact on salmon populations through the silting of spawning beds [60].

Terrain models derived from ALS data have been shown to be useful in locating effective extraction trails [58] or timber landings [61], thereby increasing efficiency and reducing both site impact like rutting and compaction [62] as well as emissions [63] arising from unnecessary terrain transport. Detailed surface features not distinguishable from ALS data with a resolution of $2-5$ points $\mathrm{m}^{-2}$ need to be quantified with specialized sensors, e.g. monitoring pitch and roll [64, 65], or can also be assessed post-harvest using drone based photogrammetry [54]. Tracks fitted to the bogie wheels increase machine flotation and reduce soil disturbance [62]. Apart from correct tire selection and inflation [66], recent engineering attempts at further reducing the impact include an extension of the length of the bogie axle itself [67] and adding another wheel set to the machine [68].

While technical developments provide essential tools for mitigating environmental damage, operator effect has been shown to explain up to $37 \%$ of productivity variance between machines [69] and is likely to account for an even larger share of site damage, although this has not been quantified. Estimates of the overall magnitude of the operator effect have improved through more specific analyses [70,71], but the absence of explanatory 


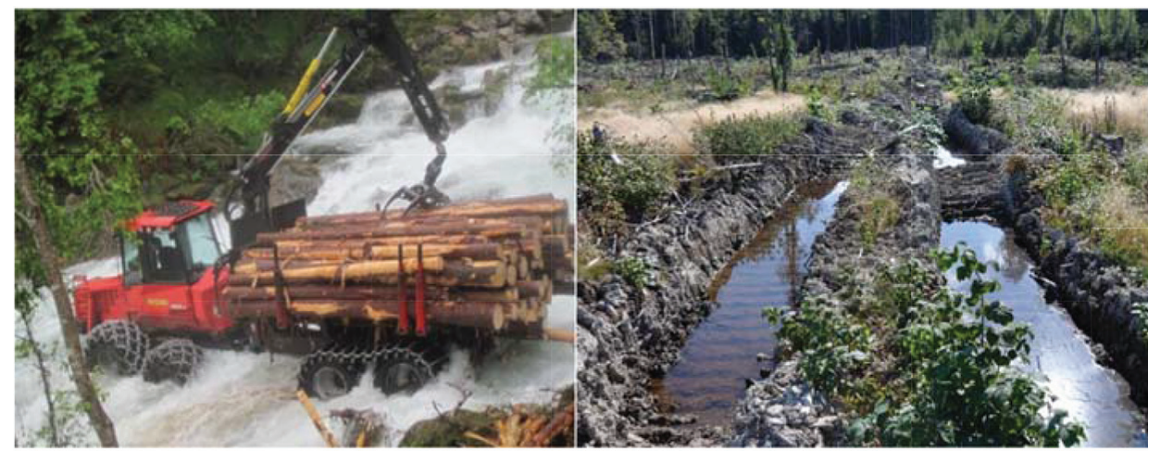

Figure 2 Forwarder fording a stream in a mountainous area (left), and (right) longer term consequences of heavy vehicle traffic during the spring thaw - here 1 year after harvesting.

factors detailing this effect represents a knowledge gap which will need to be addressed in minimizing the environmental impact of heavy forest machinery.

\subsection{Aesthetic and Cultural Heritage Impacts, as well as Impacts on the Recreational Use of Forests}

There has been some activity in remotely detecting and mapping cultural and environmental parameters. For cultural parameters, the use of ALS to detect archeological features in forests has led to considerable increase in the detection of important features [72]. Harvesters and Forwarders are equipped with monitors running mapping applications, where most are issued with layers representing the harvesting site, location of retention trees, or other areas that must be avoided. Cultural heritage sites are generally included in the information provided to the machine operator. However, the effectiveness of the approach is dependent on the accuracy of the GPS signal, and the detection of archeological features needs to be complemented with machine-mounted sensors to avoid damage to cultural heritage sites.

While there is broad agreement that the spatial configurations and properties of the landscape interact with each other [73], research work on internalizing the effect and monetary value of aesthetics has been limited in recent decades. A review of over 30 years of research considering the public preferences for forest structures, showed that people valued stands with a mixture of trees of different sizes and that larger clear cuts and obvious traces from forest operations were not appreciated [74]. However, while steep terrain harvesting is highly visible from a distance (Figure 3) the same study did point out that recreational tourists in the forest did 


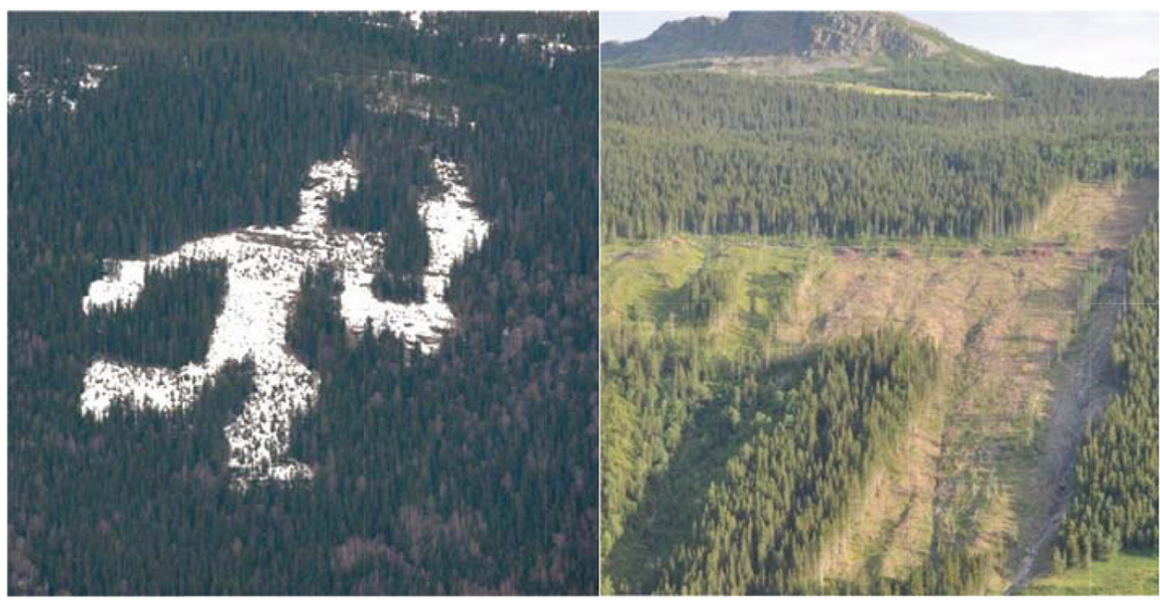

Figure 3 (left) A rare example of positive aesthetics from forest operations -the torch bearer mascot of the 1994 Winter Olympics at Lillehammer, created using cable-yarder harvesting on a steep mountainside, and (right) highly visible harvest site showing ravine landslide to the right.

appreciate openings that provided scenic views. Other studies describe the importance of both forest and individual trees that provide environmental services from a symbolic, cultural or spiritual perspective [75]. The fact that the retention of selected trees is also an important conservation measure in managed forests [76] re-emphasizes the need to apply precision forestry techniques, especially with regard to machine positioning and single tree management.

Outdoor recreation is an important part of the tourism industry in rural Norway, and can primarily be categorised as: freshwater fishing, hunting, backcountry hiking and skiing, and adventure activities [77]. Forest operations, especially wheel rutting, piling of harvesting slash and damage, or the closure of access roads can impede access to the area or detract from the backcountry experience, and are specifically highlighted in the 'Living Forests' standard [18]. Knock-on effects, such as a downturn in salmonid populations due to sedimentation of headwaters, can also have serious consequences for the nature-based tourism industry [60]. But while all Nordic countries do have specifically focused strategies or programs for outdoor recreation and nature-based tourism, there are currently no good indicators for a sustainable recreational use of forests or other natural resources [78]. However, some of these indicators could be recorded by the machines themselves. Data systems 
(CAN-bus) on modern mechanised harvesting systems provide the capability to estimate wheel rutting through rolling resistance [29] and when augmented by sensors such as laser rut measurement systems (LRMS) and enhanced machine positioning could ultimately provide detailed maps of soil impact for amelioration or monitoring. Finally, improved data and techniques for multicriteria harvesting planning, which takes into account edaphic, biological, hydrological and stakeholder information offers forest operations managers with a holistic management tool for largely avoiding both environmental and societal conflict while meeting economic goals [79].

\section{Concluding Remarks}

The availability of high resolution environmental data have become commonplace, as have a plethora of low-cost, rugged sensors that can provide visual, metric, chemical and positional data pertaining to the machines and their specific operations. Access to high precision geological and topographic maps provide operation managers at all levels with detailed information which can be used in avoiding damage to the forest. The use of drones and close range photogrammetry from consumer grade cameras allow for threedimensional data to be captured and used for monitoring, for compliance with certification standards. Improved positioning systems can both provide the machine operator with information on what to cut and what to avoid, but also to flag waypoints indicating special areas of interest discovered during harvesting. New regulations on road construction and maintenance take regard for a changing climate with more intense precipitation and ensure that water is not channelled in a way that leads to landslides or other large scale damage. Forest machines fitted with high flotation tracks provide improved access but still exceed the bearing capacity of soils in an increasingly milder winter climate. The potential for monitoring environmental performance with machine-mounted sensors is at a very early stage, but it is expected to improve rapidly as low cost sensors become commonly available, allowing for remote $3^{\text {rd }}$ party assessment of compliance with environmental standards. Ultimately, it is the machine operator who has the final capability to assess the situation in forest stands, and the responsibility to make the correct decision both with regard to the working method and the eventual suspension of operations in situations where damage to the forest obviously exceeds what could be called the social norm among professional forest engineers. 


\section{Acknowledgements}

The authors wish to acknowledge the financial support received from the ECOSERVICE and Sustainable utilization of forest resources in Norway projects, funded by the Norwegian Research Council (NFR 233641/E50 and NFR 225329/E40) as well as the support from the Norwegian Forest and Landscape Institute. We also wish to thank our colleagues for useful discussions and input, and the efforts of the two anonymous reviewers for their contributions in improving the quality of the manuscript.

\section{References}

[1] Granhus, A., G. Hylen, and J.-E. Ørnelund Nilsen, Skogen i Norge: Statistikk over skogforhold og skogressurser i Norge registrert i perioden 2005-2009, in Ressursoversikt fra Skog og landskap2012, Norwegian Forest and Landscape Institute. p. 85.

[2] Anon. The World Bank data on Population Density 2014 [cited 2014 09.10.2014]; Available from: http://data.worldbank.org/indicator/EN. POP.DNST.

[3] MoE, Natural benefits - on the values of ecosystems services: Report from an expert commission appointed by the Norwegian Government to the Ministry of the Environment on 29 August 2013., in Official Norwegian Report NOU 2013: 10 Summary2013, Norwegian Ministry of the Environment Oslo. p. 38.

[4] Daily, G. C., S. Polasky, J. Goldstein, P. M. Kareiva, H. A. Mooney, L. Pejchar, T. H. Ricketts, J. Salzman, and R. Shallenberger, Ecosystem services in decision making: time to deliver. Frontiers in Ecology and the Environment, 2009. 7(1): p. 21-28.

[5] Clarke, L. and K. Jiang, Chapter 6: Assessing transformation pathways, in Climate Change Mitigation - Contribution by Working Group III to the Fifth IPCC Assessment Report. 2014: Geneva. p. 141.

[6] Luyssaert, S., M. Jammet, P. Stoy, S. Estel, J. Pongratz, E. Ceschia, G. Churkina, A. Don, K.-H. Erb, M. Ferlicoq, B. Gielen, T. Grünwald, R. Houghton, K. Klumpp, A. Knohl, T. Kolb, and et al., Land management and land-cover change have impacts of similar magnitude on surface temperature. Nature Climate Change, 2014. 4(5): p. 389-393.

[7] Lambin, E. F. and P. Meyfroidt, Global land use change, economic globalization, and the looming land scarcity. Proceedings of the National Academy of Sciences, 2011. 108(9): p. 3465-3472. 
[8] Kraxner, F., E.-M. Nordström, P. Havlík, M. Gusti, A. Mosnier, S. Frank, H. Valin, S. Fritz, S. Fuss, G. Kindermann, I. McCallum, N. Khabarov, H. Böttcher, L. See, K. Aoki, E. Schmid, L. Máthé, and M. Obersteiner, Global bioenergy scenarios - Future forest development, land-use implications, and trade-offs. Biomass and Bioenergy, 2013. 57(0): p. 86-96.

[9] LMD, White paper on agricultural and food policy, 2011, Landbruksog matdepartement (LMD) [The Ministry of agriculture and food].

[10] Duncker, P. S., S. M. Barreiro, G. M. Hengeveld, T. Lind, W. L. Mason, S. Ambrozy, and H. Spiecker, Classification of Forest Management Approaches: A New Conceptual Framework and Its Applicability to European Forestry. Ecology and Society, 2012. 17(4).

[11] Başkent, E., S. Keleş, A. Kadiogullari, and Ö. Bingöl, Quantifying the Effects of Forest Management Strategies on the Production of Forest Values: Timber, Carbon, Oxygen, Water, and Soil. Environmental Modeling \& Assessment, 2011. 16(2): p. 145-152.

[12] Kimmins, J. H., Balancing act: environmental issues in forestry. 2011: UBC Press.

[13] Reinhard, S., C. A. Knox Lovell, and G. J. Thijssen, Environmental efficiency with multiple environmentally detrimental variables; estimated with SFA and DEA. European Journal of Operational Research, 2000. 121(2): p. 287-303.

[14] Dios-Palomares, R. and J. M. Martínez-Paz, Technical, quality and environmental efficiency of the olive oil industry. Food Policy, 2011. 36(4): p. 526-534.

[15] Thanh Nguyen, T., V.-N. Hoang, and B. Seo, Cost and environmental efficiency of rice farms in South Korea. Agricultural Economics, 2012. 43(4): p. 369-378.

[16] FSC, FSC Principles and Criteria for Forest Stewardship, in FSC-STD01-001 (version 4)2002, Forest Stewardship Council: Bonn. p. 13.

[17] PEFC, Living Forests - Standard for sustainable forest management in Norway, 2006. p. 38.

[18] Anon., Living Forests: Standard for sustainable forest management in Norway, 2006: Oslo. p. 38.

[19] Ottaviani, G., B. Talbot, M. Nitteberg, and K. Stampfer, Workload Benefits of Using a Synthetic Rope Strawline in Cable Yarder Rigging in Norway. Croatian Journal of Forest Engineering, 2011. 32(2). 
[20] Aalmo, G. O. and B. Talbot, Operator performance improvement through training in a controlled cable yarding study. International Journal of Forest Engineering., 2014 25(1):p. 5-13.

[21] Devoli, G., T. Bargel, A. Taurisano, T. Wiig, H. Berg, E. Øydvin, R. Hermanns, and L. Hansen, Identifying Needs and Areas for Future Landslide Hazard Mapping in Norway, in Landslide Science and Practice, C. Margottini, P. Canuti, and K. Sassa, Editors. 2013, Springer Berlin Heidelberg. p. 223-230.

[22] Ziesak, M., A. F. Marques, J. Rasinmaki, C. Rosset, K. Nummila, J. Scholz, M. Mittlboeck, J. Pinho de Sousa, J. Häkli, and D. Rommel, Advances in forestry control and automation systems i Europe - FOCUS: the concept idea in a multinational EU research project, in Proceedings of the 6th Precision Forestry Symposium: The anchor of your value chain, P. Ackerman, E. Gleasure, and H. Ham, Editors. 2014, Faculty of AgriSciences, Stellenbosch University: Stellenbosch, South Africa. p. 114.

[23] Beaudoin, D., J. M. Frayret, and L. LeBel, Hierarchical forest management with anticipation: an application to tactical-operational planning integration. Canadian Journal of Forest Research, 2008. 38(8): p. 2198-2211.

[24] Väätäinen, K., A. Asikainen, L. Sikanen, and A. Ala-Fossi, The cost effect of forest machine relocations on logging costs in Finland. Forestry Studies Metsanduslikud Uurimused, 2006. 45: p. 135-141.

[25] Smaltschinski, T., U. Seeling, and G. Becker, Clustering forest harvest stands on spatial networks for optimised harvest scheduling. Annals of Forest Science, 2012. 69(5): p. 651-657.

[26] Kolka, R., A. Steber, K. Brooks, C. H. Perry, and M. Powers, Relationships between Soil Compaction and Harvest Season, Soil Texture, and Landscape Position for Aspen Forests. Northern Journal of Applied Forestry, 2012. 29(1): p. 21-25.

[27] Borges, P., E. Bergseng, and T. Eid, Adjacency constraints in forestry a simulated annealing approach comparing different candidate solution generators. 2014. Vol. 6. 2014.

[28] Strandgard, M., D. Walsh, and M. Acuna, Estimating harvester productivity in Pinus radiata plantations using StanForD stem files. Scandinavian Journal of Forest Research, 2012. 28(1): p. 73-80.

[29] Suvinen, A. and M. Saarilahti, Measuring the mobility parameters of forwarders using GPS and CAN bus techniques. Journal of Terramechanics, 2006. 43(2): p. 237-252. 
[30] Palander, T., Y. Nuutinen, A. Kariniemi, and K. Väätäinen, Automatic Time Study Method for Recording Work Phase Times of Timber Harvesting. Forest Science, 2013. 59(4): p. 472-483.

[31] Næsset, E. and J. G. Gjevestad, Performance of GPS Precise Point Positioning Under Conifer Forest Canopies. Photogrammetric Engineering \& Remote Sensing, 2008. 74(5): p. 661-668.

[32] Ringdahl, O., P. Hohnloser, T. Hellström, J. Holmgren, and O. Lindroos, Enhanced Algorithms for Estimating Tree Trunk Diameter Using 2D Laser Scanner. Remote Sensing, 2013. 5(10): p. 4839-4856.

[33] Mousazadeh, H., A technical review on navigation systems of agricultural autonomous off-road vehicles. Journal of Terramechanics, 2013. 50(3): p. 211-232.

[34] Miettinen, M., M. Ohman, A. Visala, and P. Forsman. Simultaneous Localization and Mapping for Forest Harvesters. in Robotics and Automation, 2007 IEEE International Conference on. 2007.

[35] Wang, J., C. B. LeDoux, and Y. Li, Simulating Cut-to-Length Harvesting Operations in Appalachian Hardwoods. International Journal of Forest Engineering, 2005. 16(2): p. 11-27.

[36] Gerasimov, Y., V. Senkin, and K. Väätäinen, Productivity of singlegrip harvesters in clear-cutting operations in the northern European part of Russia. European Journal of Forest Research, 2012. 131(3): p. 647-654.

[37] Barth, A., J. Möller, L. Wilhelmsson, J. Arlinger, R. Hedberg, and U. Söderman, A Swedish case study on the prediction of detailed product recovery from individual stem profiles based on airborne laser scanning. Annals of Forest Science, 2014: p. 1-10.

[38] Murphy, G., Determining Stand Value and Log Product Yields Using Terrestrial Lidar and Optimal Bucking: A Case Study. Journal of Forestry, 2008. 106(6): p. 317-324.

[39] Chauhan, S., J. M. Frayret, and L. LeBel, Supply network planning in the forest supply chain with bucking decisions anticipation. Annals of Operations Research, 2011. 190(1): p. 93-115.

[40] Dems, A., L.-M. Rousseau, and J.-M. Frayret, Effects of different cut-to-length harvesting structures on the economic value of a wood procurement planning problem. Annals of Operations Research, 2013: p. 1-22.

[41] Manner, J., T. Nordfjell, and O. Lindroos, Effects of the number of assortments and log concentration on time consumption for forwarding. Silva Fennica, 2013. 47(4): p. 19p. 
[42] Arce, J. E., C. Carnieri, C. R. Sanquetta, and A. F. Filho, A Forest-Level Bucking Optimization System that Considers Customer's Demand and Transportation Costs. Forest Science, 2002. 48(3): p. 492-503.

[43] Gautam, S., L. LeBel, and D. Beaudoin, Agility capabilities in wood procurement systems: a literature synthesis. International Journal of Forest Engineering, 2013. 24(3): p. 216-232.

[44] Osterkamp, W. R., C. R. Hupp, and M. Stoffel, The interactions between vegetation and erosion: new directions for research at the interface of ecology and geomorphology. Earth Surface Processes and Landforms, 2012. 37(1): p. 23-36.

[45] Roa-García, M. C., S. Brown, H. Schreier, and L. M. Lavkulich, The role of land use and soils in regulating water flow in small headwater catchments of the Andes. Water Resources Research, 2011. 47(5): p. W05510.

[46] Laudon, H., R. Sponseller, R. Lucas, M. Futter, G. Egnell, K. Bishop, A. Ågren, E. Ring, and P. Högberg, Consequences of More Intensive Forestry for the Sustainable Management of Forest Soils and Waters. Forests, 2011. 2(1): p. 243-260.

[47] Sundberg, U. and C. R. Silversides, Operational efficiency in Forestry. Forestry Sciences. 1998, Dordrecht: Kluwer Academic Publishers. 219.

[48] Aruga, K., J. Sessions, and E. S. Miyata, Forest road design with soil sediment evaluation using a high-resolution DEM. Journal of Forest Research, 2005. 10(6): p. 471-479.

[49] Contreras, M., P. Aracena, and W. Chung, Improving Accuracy in Earthwork Volume Estimation for Proposed Forest Roads Using a High-Resolution Digital Elevation Model. Croatian Journal of Forest Engineering, 2012. 33(1): p. 125-142.

[50] James, L. A., D. G. Watson, and W. F. Hansen, Using LiDAR data to map gullies and headwater streams under forest canopy: South Carolina, USA. CATENA, 2007. 71(1): p. 132-144.

[51] Perroy, R. L., B. Bookhagen, G. P. Asner, and O. A. Chadwick, Comparison of gully erosion estimates using airborne and ground-based LiDAR on Santa Cruz Island, California. Geomorphology, 2010. 118(3-4): p. 288-300.

[52] Johnsrud, T.-E., J. Bjerketvedt, J. K. Lileng, N. O. Kyllo, and D. Skjølaas, Normaler for landbruksveier - med byggebeskrivelse [Prescriptions for low volume roads - with construction guidelines], 2013, Norwegian Agricultural Authority. p. 82. 
[53] Megahan, W. F. and W. J. Kidd, Effects of logging and logging roads on erosion and sediment deposition from steep terrain Journal of Forestry 1972. 70(3): p. 136-141.

[54] Pierzcha1,a, M., B. Talbot, and R. Astrup, Estimating Soil Displacement from Timber Extraction Trails in Steep Terrain: Application of an Unmanned Aircraft for 3D Modelling. Forests, 2014. 5(6): p. 1212-1223.

[55] Smidt, M. F. and R. K. Kolka, Alternative skid trail retirement options for steep terrain logging, in The 24th Annual Meeting of The Council of Forest Engineering (COFE). Appalachian Hardwoods: Managing Change, J. Wang, M. Wolford, and J. F. McNeel, Editors. 2001, USDA Forest Service: Snowshoe, West Virginia. p. 6.

[56] Christopher, E., A and R. Visser, Methodology for evaluatingpost harvest erosion risk for the protection of water quality. New Zealand Journal of Forestry, 2007: p. 20-25.

[57] Sawyers, B. C., M. C. Bolding, W. M. Aust, and W. A. Lakel, Effectiveness and implementation costs of overland skid trail closure techniques in the Virginia Piedmont. Journal of Soil and Water Conservation, 2012. 67(4): p. 300-310.

[58] Søvde, N. E., A. Løkketangen, and B. Talbot, Applicability of the GRASP metaheuristic method in designing machine trail layout. Forest Science and Technology, 2013. 9(4): p. 187-194.

[59] SSB. Focus on Forests. 10.04.20 2012 [cited 2012 30.06]; Available from: http://www.ssb.no/10/04/20/skog/.

[60] Egglishaw, H., R. Gardiner, and J. Foster, Salmon catch decline and forestry in Scotland. Scottish Geographical Magazine, 1986. 102(1): p. 57-61.

[61] Contreras, M. and W. Chung, A computer approach to finding an optimal log landing location and analyzing influencing factors for ground-based timber harvesting. Canadian Journal of Forest Research, 2007. 37(2): p. 276-292.

[62] Sakai, H., T. Nordfjell, K. Suadicani, B. Talbot, and E. Bøllehuus, Soil compaction on forest soils from different kinds of tires and tracks and possibility of accurate estimate. Croatian Journal of Forest Engineering, 2008. 29(1): p. 15-27.

[63] Timmermann, V. and J. Dibdiakova, Greenhouse gas emissions from forestry in East Norway. The International Journal of Life Cycle Assessment, 2014. 19(9): p. 1593-1606.

[64] Søvde, N. E., B. Talbot, J. Bjerketvedt, and M. Pierzchala, Improving parameter estimates in modelling the influence of pitch and roll on 
forwarder driving speed, in Proceedings of the 6th Precision Forestry Symposium: The anchor of your value chain, P. Ackerman, E. Gleasure, and H. Ham, Editors. 2014, Faculty of AgriSciences, Stellenbosch University: Stellenbosch, South Africa.

[65] Ringdahl, O., T. Hellström, I. Wästerlund, and O. Lindroos, Estimating wheel slip for a forest machine using RTK-DGPS. Journal of Terramechanics, 2012. 49(5): p. 271-279.

[66] Eliasson, L., Effects of forwarder tyre pressure on rut formation and soil compaction. Silva Fennica, 2005. 39(4): p. 549-557.

[67] Edlund, J., E. Keramati, and M. Servin, A long-tracked bogie design for forestry machines on soft and rough terrain. Journal of Terramechanics, 2013. 50(2): p. 73-83.

[68] Horn, R., J. Vossbrink, and S. Becker, Modern forestry vehicles and their impacts on soil physical properties. Soil and Tillage Research, 2004. 79(2): p. 207-219.

[69] Purfürst, F. T. and J. Erler, The Human Influence on Productivity in Harvester Operations. International Journal of Forest Engineering, 2011. 22(2): p. 15-22.

[70] Purfürst, F. T., Learning curves of harvester operators. Croatian Journal of Forest Engineering, 2010. 31(2): p. 89-97.

[71] Lindroos, O., Scrutinizing the Theory of Comparative Time Studies with Operator as Block Effect. International Journal of Forest Engineering, 2010. 21(1): p. 10.

[72] Risb $\varnothing 1$, O., C. Briese, M. Doneus, and A. Nesbakken, Monitoring cultural heritage by comparing DEMs derived from historical aerial photographs and airborne laser scanning. Journal of Cultural Heritage, 2014.

[73] Nielsen, A. B., E. Heyman, and G. Richnau, Liked, disliked and unseen forest attributes: Relation to modes of viewing and cognitive constructs. Journal of Environmental Management, 2012. 113(0): p. $456-466$.

[74] Gundersen, V. S. and L. H. Frivold, Public preferences for forest structures: A review of quantitative surveys from Finland, Norway and Sweden. Urban Forestry \& Urban Greening, 2008. 7(4): p. 241-258.

[75] Laband, D. N., The neglected stepchildren of forest-based ecosystem services: Cultural, spiritual, and aesthetic values. Forest Policy and Economics, 2013. 35(0): p. 39-44.

[76] Schei, F. H., H. H. Blom, I. Gjerde, J.-A. Grytnes, E. Heegaard, and M. Sætersdal, Conservation of epiphytes: Single large or several small host trees? Biological Conservation, 2013. 168(0): p. 144-151. 
[77] Tangeland, T., Ø. Aas, and A. Odden, The Socio-Demographic Influence on Participation in Outdoor Recreation Activities - Implications for the Norwegian Domestic Market for Nature-Based Tourism. Scandinavian Journal of Hospitality and Tourism, 2013. 13(3): p. 190-207.

[78] Sievänen, T., D. Edwards, P. Fredman, F. Søndergaard Jensen, and O. I. Vistad, Indicators for sustainable recreational use of forests and other natural resources - experiences from Northern Europe, in Protected Areas and Place Making: How do we provide conservation, landscape management, tourism, human health and regional development?, T. C. Magro, et al., Editors. 2013, Forestry Sciences Departament - ESALQ/USP: Foz do Iguacu, Brazil. p. 204.

[79] Pasalodos-Tato, M., A. Mäkinen, J. Garcia-Gonzalo, J. G. Borges, T. Lämås, and L. O. Eriksson, Review. Assessing uncertainty and risk in forest planning and decision support systems: review of classical methods and introduction of new approaches. 2013, 2013. 22(2).

\section{Biographies}

Bruce Talbot is researcher in forest operations and works with a wide range of related issues in biomass procurement and timber harvesting and supply logistics. More recently, his research work has centered around steep terrain logging in Norway focusing both on the productivity and the environmental impact of these harvesting systems.

Rasmus Astrup is researcher and Head of the Department of forest resources. He works across multiple disciplines although his main research interest is in forest inventory and forest modelling with a special emphasis on developing new approaches for quantification of various aspects of forestry. Within forest inventory his main interest is in the development of efficient and robust methods combining remote sensing with field-based inventories. 
